Earthquake Hazards Ground Motion Investigations

\title{
P- and S-wave Velocity Models Incorporating the Cascadia Subduction Zone for 3D Earthquake Ground Motion Simulations, Version 1.6-Update for Open-File Report 2007-1348
}

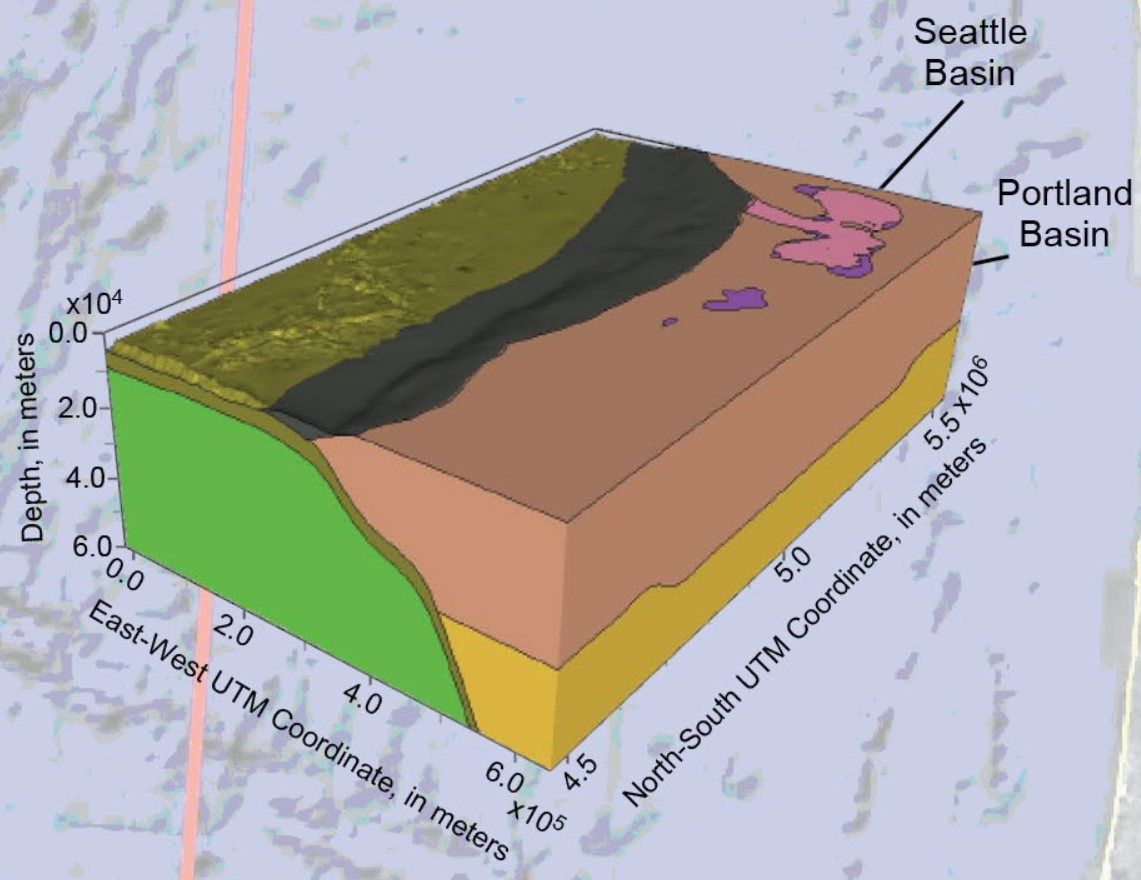

Open-File Report 2017-1152

Version 1.1, September 2019

Supersedes USGS Open-File Report 2007-1348 
Cover. Base image is from figure 1, this report, and is the region of velocity models described in this report. Geologic model volume including the Cascadia subduction zone is from figure 3 , this report. 


\section{P- and S-wave Velocity Models Incorporating the Cascadia Subduction Zone for 3D Earthquake Ground Motion Simulations, Version 1.6-Update for Open-File Report 2007-1348}

By William J. Stephenson, Nadine G. Reitman, and Stephen J. Angster

Earthquake Hazards Ground Motion Investigations

Open-File Report 2017-1152

Version 1.1, September 2019

Supersedes USGS Open-File Report 2007-1348 


\title{
U.S. Department of the Interior \\ RYAN K. ZINKE, Secretary
}

\section{U.S. Geological Survey William H. Werkheiser, Deputy Director exercising the authority of the Director}

\author{
U.S. Geological Survey, Reston, Virginia: 2017 \\ First release: 2017 \\ Revised: September 10, 2019 (ver. 1.1) \\ Supersedes USGS Open-File Report 2007-1348
}

\begin{abstract}
For more information on the USGS - the Federal source for science about the Earth, its natural and living resources, natural hazards, and the environment-visit https://www.usgs.gov or call 1-888-ASK-USGS.

For an overview of USGS information products, including maps, imagery, and publications, visit https://store.usgs.gov.
\end{abstract}

Any use of trade, firm, or product names is for descriptive purposes only and does not imply endorsement by the U.S. Government.

Although this information product, for the most part, is in the public domain, it also may contain copyrighted materials as noted in the text. Permission to reproduce copyrighted items must be secured from the copyright owner.

Suggested citation:

Stephenson, W.J., Reitman, N.G., and Angster, S.J., 2017, P- and S-wave velocity models incorporating the Cascadia subduction zone for 3D earthquake ground motion simulations, version 1.6 - Update for Open-File Report 2007-1348 (ver. 1,1, Sept. 10, 2019): U.S. Geological Survey Open-File Report 2017-1152, 17 p., https://doi.org/10.3133/ ofr20171152. [Supersedes USGS Open-File Report 2007-1348.]

ScienceBase data release available at https://doi.org/10.5066/F7NSOSWM

ISSN 2331-1258 (online) 


\section{Acknowledgments}

The $V_{p}$ and $V_{S}$ property volumes of model V1.6 were greatly improved by feedback from end-users including Art Frankel (U.S. Geological Survey [USGS]), Andy Delorey (Los Alamos National Laboratory), and John Vidale (University of Washington). We thank Jack Odum and Robert Williams (USGS) for their technical reviews, which greatly improved this manuscript. Special thanks to Jordan Bretthauer (USGS) for assistance in developing figure 1 of this report. Discussions with numerous collaborators and other interested parties seeking components of the model for their research helped prompt us to formally complete this updated documentation. This research was supported by funding from the USGS Earthquake Hazards Program. 



\section{Contents}

Acknowledgments ….......................................................................................................................

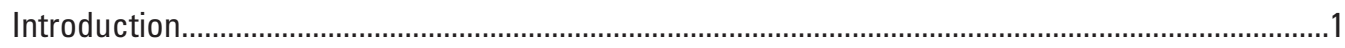

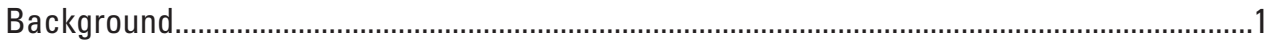

Investigations Using Model V1.3 ............................................................................................

Primary Differences Between Models V1.3 and V1.6 …............................................................

The Primary Geology-Based Model Units and Their Velocity Properties ........................................

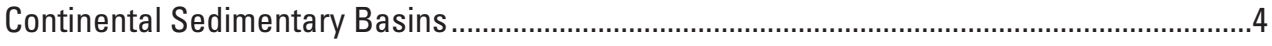

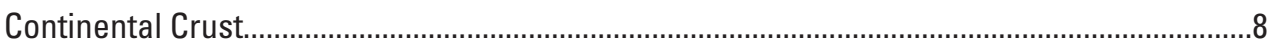

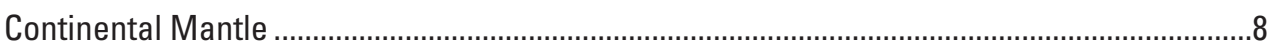

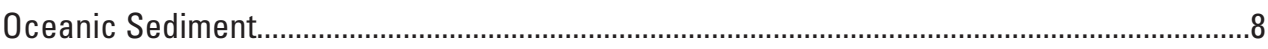

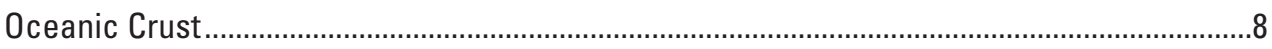

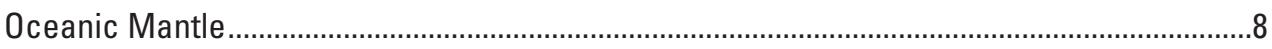

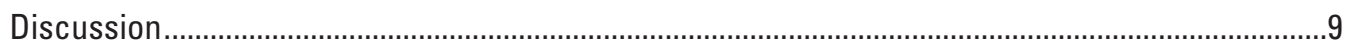

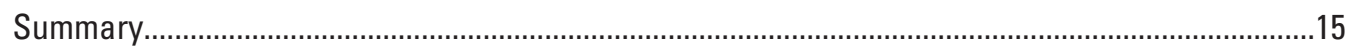

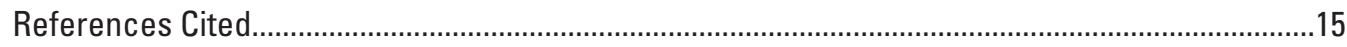

\section{Figures}

1. Map showing region of velocity models described in this report......................................

2. Contour map of Cascadia subducting slab upper surface in model region ........................3

3. Geologic model volume including the Cascadia subduction zone......................................5

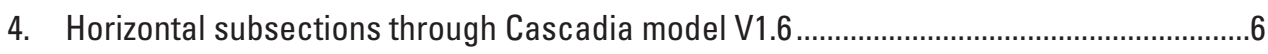

5. Sliced view of Puget Lowland with Seattle basin ............................................................

6. East-west slices through $V_{s}$ model, spaced every 200 kilometers...................................10

7. $V_{s}$ horizontal model slices at 9,000 meter $(\mathrm{m})$ to $45,000 \mathrm{~m}$ depth intervals, spaced

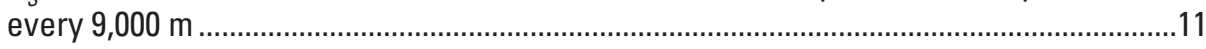

8. East-west slices through $V_{p}$ model, spaced every 200 kilometers.................................12

9. $V_{p}$ horizontal model slices at 9,000 meter $(\mathrm{m})$ to $45,000 \mathrm{~m}$ depth intervals, spaced every $9,000 \mathrm{~m}$.........................................................................................................13

10. $V_{p} / V_{s}$ horizontal model slices from 0 meter $(\mathrm{m})$ to $45,000 \mathrm{~m}$ depth, spaced every $9,000 \mathrm{~m}$ 


\section{Conversion Factors}

International System of Units to U.S. customary units

\begin{tabular}{lcl}
\hline \multicolumn{1}{c}{ Multiply } & \multicolumn{1}{c}{ By } & \multicolumn{1}{c}{ To obtain } \\
\hline & Length & \\
\hline centimeter $(\mathrm{cm})$ & 0.3937 & inch (in.) \\
meter $(\mathrm{m})$ & 3.281 & foot $(\mathrm{ft})$ \\
kilometer $(\mathrm{km})$ & 0.6214 & mile $(\mathrm{mi})$ \\
\hline & Density & \\
\hline gram per cubic centimeter $\left(\mathrm{g} / \mathrm{cm}^{3}\right)$ & 62.4220 & pound per cubic foot $\left(\mathrm{lb} / \mathrm{ft}^{3}\right)$ \\
\hline
\end{tabular}




\title{
P- and S-wave Velocity Models Incorporating the Cascadia Subduction Zone for 3D Earthquake Ground Motion Simulations-Update for Open-File Report 2007-1348
}

\author{
Version 1.6
}

By William J. Stephenson, ${ }^{1}$ Nadine G. Reitman, ${ }^{2}$ and Stephen J. Angster ${ }^{3}$

\section{Introduction}

In support of earthquake hazards studies and ground motion simulations in the Pacific Northwest, threedimensional (3D) P- and S-wave velocity $\left(V_{P}\right.$ and $V_{S}$, respectively) models incorporating the Cascadia subduction zone were previously developed for the region encompassed from about $40.2^{\circ} \mathrm{N}$. to $50^{\circ} \mathrm{N}$. latitude, and from about $122^{\circ} \mathrm{W}$. to $129^{\circ} \mathrm{W}$. longitude (fig. 1). This report describes updates to the Cascadia velocity property volumes of model version 1.3 ([V1.3]; Stephenson, 2007), herein called model version 1.6 (V1.6). As in model V1.3, the updated V1.6 model volume includes depths from 0 kilometers $(\mathrm{km})$ (mean sea level) to $60 \mathrm{~km}$, and it is intended to be a reference for researchers who have used, or are planning to use, this model in their earth science investigations. To this end, it is intended that the $V_{P}$ and $V_{S}$ property volumes of model V1.6 will be considered a template for a community velocity model of the Cascadia region as additional results become available. With the recent and ongoing development of the National Crustal Model (NCM; Boyd and Shah, 2016), we envision any future versions of this model will be directly integrated with that effort.

\section{Background}

The Cascadia subduction zone stretches for over $1,000 \mathrm{~km}$, from the Mendocino Triple Junction off the northern California coast northward to Vancouver Island,

${ }^{1}$ U.S. Geological Survey.

${ }^{2}$ University of Colorado Boulder, Boulder, Colo.

${ }^{3}$ University of Nevada, Reno, Nev.
Canada (fig. 2). The primary reasons for developing these model volumes are (1) for simulating strong earthquake ground motions in the urbanized sedimentary basins of western Washington and Oregon, and (2) for simulating tsunami effects from a great (moment magnitude [M] 8-9) Cascadia subduction zone earthquake. As such, these are geophysical property models constrained by first-order geologic boundaries only. We do not attempt to explicitly represent detailed geologic terranes in the model volume unless they were deemed important for ground motion variability in urbanized regions. Thus, unique terranes within the continental crust, such as Siletz (see Trehu and others, 1994) or Wrangellia (Jones and others, 1977) are not treated as unique units within the model; however, their effects on ground motions are essentially represented through the use of passive- and active-source tomographic imaging results. Similarly, serpentinized mantle (for example, Bostock and others, 2002) is not explicitly included, but its existence can be partially inferred from the $V_{S}$ and $V_{P}$ property data.

The P- and S-velocity volumes of model V1.6 were developed with EarthVision software, version. 9.0, on the Linux operating system. Matlab version R2015b was used for carrying out quality-control of the model volumes output in Institute of Electrical and Electronics Engineers, Incorporated (IEEE) binary format from EarthVision. While a wealth of published information for the Cascadia region has been incorporated in the development of these models, significant smoothing during extrapolation and interpolation in portions of the model were required to create the model interfaces and geophysical property volumes. Because there are many areas within the model where published data are sparse or of low resolution, there is very likely significant uncertainty and therefore subjectivity involved in building model horizons and in populating the model volumes. 


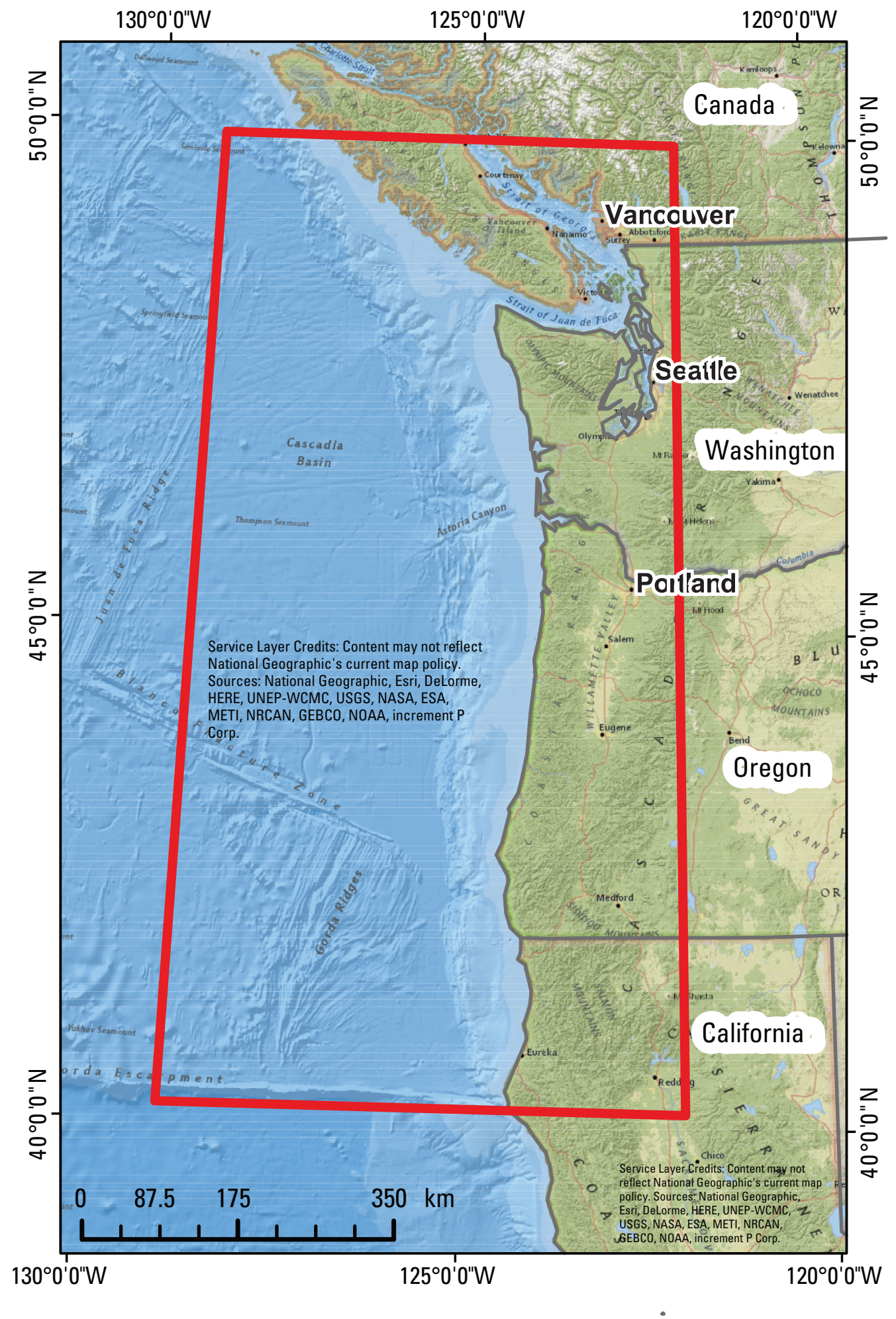

Figure 1. Region of velocity models described in this report. Base map shows the urban centers of Portland, Oreg., Seattle, Wash., and Vancouver, British Columbia. Red polygon is approximate boundary of velocity property volumes that include the Cascadia subduction zone. Latitude and longitude coordinates at corners of red polygon are, clockwise from upper left, $50^{\circ} \mathrm{N}$., $129^{\circ} \mathrm{W}$.; $50^{\circ} \mathrm{N}$., $122^{\circ} \mathrm{W}$.; $40.2^{\circ} \mathrm{N} ., 122^{\circ} \mathrm{W}$.; and $40.2^{\circ} \mathrm{N} ., 1^{\circ} \mathrm{W}$. Projection is World Geodetic System 1984 (WGS 84) datum. 


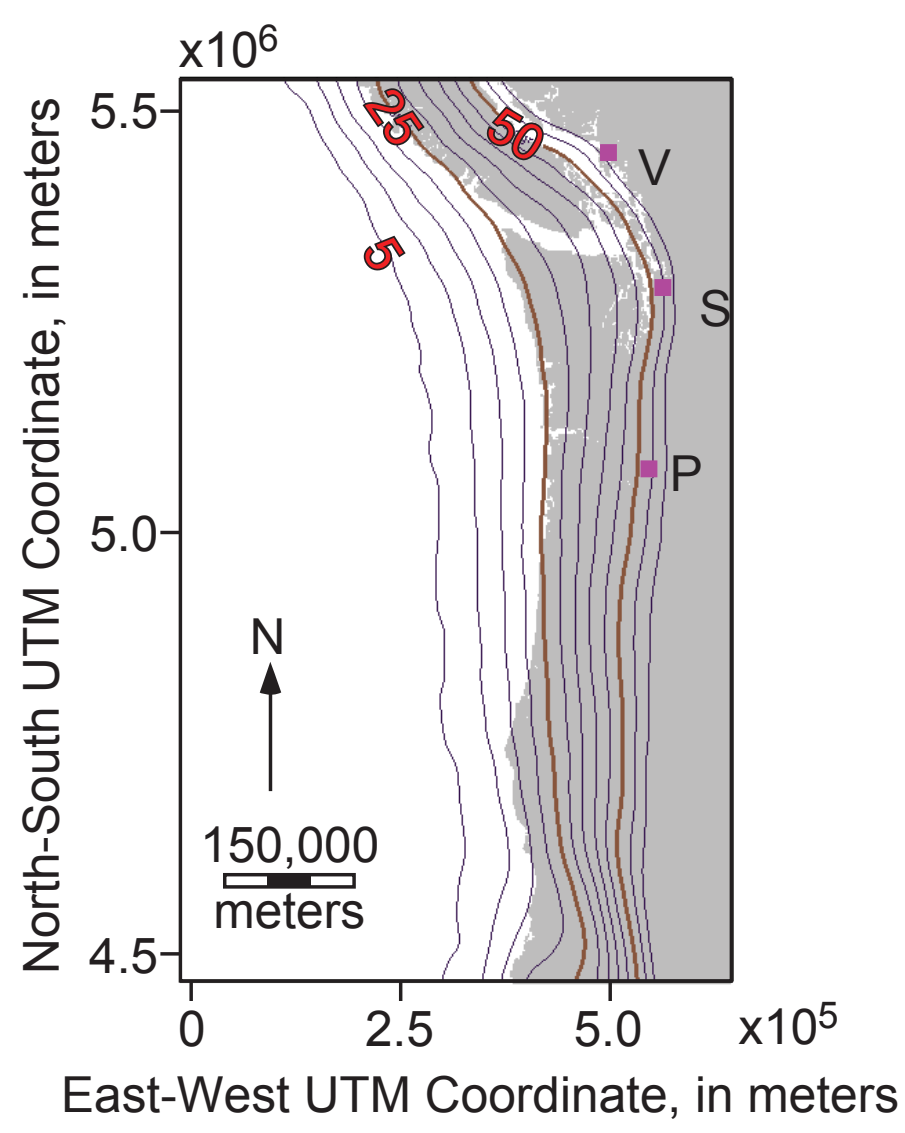

Figure 2. Contour map of Cascadia subducting slab upper surface in model region (McCrory and others, 2012; Blair and others, 2013). Contours are from $5 \mathrm{~km}$ to $60 \mathrm{~km}$ depth, in kilometers below mean sea-level. Gray region is continental North America, with the cities of Vancouver, British Columbia (V), Seattle, Wash. $(\mathrm{S})$, and Portland, Oreg. (P), shown. UTM, Universal Transverse Mercator.

The model volume incorporates bathymetry but does not incorporate topography. Topography is not included in model V1.6 because the objective in developing these models was for use in 3D finite-difference ground motion calculations with modeling codes that do not allow grid points for terrain. However, topography will be included in any future update of this model, likely as part of the NCM, to accommodate advances in ground motion simulations. Finally, there has been limited research into adding a geotechnical velocity gradient to approximate weathering in the shallow crust (for example, Shaw and others, 2015) and adding randomness to the velocity property values. These additional parametrizations show promise for improving ground motion simulations, but have not been included in model V1.6.

\section{Investigations Using Model V1.3}

The first released version of model V1.3 found important use in the seismological and physics communities. A noncomprehensive list of published investigations using all or part of model V1.3 includes: (1) Frankel and Stephenson (2000) and Stephenson and Frankel (2003), who used subregions of V1.3 for ground motion simulations valid up to 0.1 hertz (Hz); (2) Frankel and others (2007) used a larger subregion of model V1.3 that included the structural and geophysical detail in the southern Puget Lowland for scenario earthquake simulations, including 3D basin effects in the Seattle basin, that were incorporated into the Seattle Urban Seismic Hazard Maps; (3) Olsen and others (2008) used the entire model volume to carry out a deterministic Cascadia simulation up to $0.5 \mathrm{~Hz}$ using a Sumatra-Andaman Islands rupture scenario; (4) Delorey and Vidale (2011) used the model for comparison with $V_{S}$ derived from ambient noise tomography in the Seattle basin; (5) Molnar and others (2014) used the northern half of the model as a starting point for ground motion modeling and seismic hazards investigations in the Vancouver, British Columbia region; and (6) Wagner and others (2012) used the model in a theoretical physics experiment to test the weak equivalence principle.

\section{Primary Differences Between Models V1.3 and V1.6}

Several important modifications were done in the development of model V1.6. First, density (rho) values for all V1.6 model units are not provided as a separate property volume as was done for model V1.3. Instead, end-users will need to estimate the rho parameters for their specific purpose. Lacking an alternative approach, we still recommend calculation of rho directly from P-wave velocity $\left(V_{P}\right)$ using the empirical relationship of Brocher (2005), which is approximately the deterministic form of the Nafe-Drake law. This empirical equation is:

$$
\begin{aligned}
\text { rho }= & 1.6612 * V_{P}-0.4721 * V_{P}^{2}+0.0671 * V_{P}^{3}- \\
& 0.0043 * V_{P}^{4}+0.000106 * V_{P}^{5}
\end{aligned}
$$

where $V_{P}$ is in kilometers per second $(\mathrm{km} / \mathrm{s})$ and rho is density in grams per cubic centimeter) $\left(\mathrm{g} / \mathrm{cm}^{3}\right)$. After this calculation, we recommend the minimum and maximum non-water densities be constrained to 2.0 and $3.5 \mathrm{~g} / \mathrm{cm}^{3}$, respectively, and ocean water be set to $1.028 \mathrm{~g} / \mathrm{cm}^{3}$.

Within the model volume, several notable changes to geologic structure and property parameter datasets were made: (1) the surficial contact between Quaternary and Tertiary sediments in western Washington State was redefined at higher resolution using the geologic map of Schuster (2005); (2) $V_{S}$ for the continental crust and mantle were modified to use the tomographic results of Moschetti and others (2007), with $V_{P}$ in these units now calculated from empirical relationships 
of Brocher (2005) at locations distal to the Puget Lowland; (3) bathymetry was updated to use the General Bathymetric Chart of the Oceans 2014 (GEBCO_2014) gridded data (GEBCO, 2015); (4) the surface geometry of the subducting slab was updated with the data of McCrory and others (2012) and Blair and others (2013); (5) the base of the subducting oceanic crust was redefined from downward projection of a smoothed version of the data of McCrory and others (2012) and Blair and others (2013).

\section{The Primary Geology-Based Model Units and Their Velocity Properties}

The following section is from Stephenson (2007). The backbone of the velocity property volumes is the geologic model, consisting of autonomous units representing simplified geologic units. Six primary units were defined for this model. As shown in figure 3, these are: (1) continental sedimentary basins (subdivided into Quaternary and Tertiary basin units), (2) continental crust, (3) continental mantle, (4) oceanic sediments, (5) oceanic crust, and (6) oceanic mantle.

In addition to the Cascadia subduction interface, the Seattle fault was incorporated into these models because of its use as a seismogenic source in the Seattle Urban Hazards Maps (Frankel and others, 2007; fig. 4). The modeling demands for the smaller-scale Seattle maps also drove the more detailed, complex overall appearance of the Puget Lowland region in the current velocity models. The Seattle fault delimits the southern edge of the Seattle basin and thrusts crystalline crust over basin sediments, creating a sharp lateral velocity contrast. Its surface trace was extracted from Blakely and others (2002) and projected to a depth of about $20 \mathrm{~km}$ assuming a $45^{\circ}$ south dip. This dip angle is a median value based on the range of dips published from seismic reflection surveys (Pratt and others, 1997; Johnson and others, 1999; ten Brink and others, 2002; Calvert and others, 2003). Additional crustal faults can be incorporated into the model as interest and additional information arise.

Published velocity information for the Cascadia region includes both regional $V_{P}$ and $V_{S}$ datasets, but there is limited overlap in the locations of the $V_{P}$ and the $V_{S}$ studies. In general, we used the available velocity data independently; however, in many of the geologic units, $V_{P}$ is derived from $V_{S}$, or $V_{S}$ from $V_{P}$, depending on data coverage. In units other than the continental sedimentary basins, the empirical relations of Brocher (2005) are used for the velocity conversion. The velocities within the Quaternary and Tertiary sedimentary basin units are described in detail in a later section, entitled "Continental Sedimentary Basins."

\section{Continental Sedimentary Basins}

Continental sedimentary basin deposits are subdivided into Quaternary and Tertiary geologic units. The thickness of the Quaternary units through the southern Puget Lowland was constrained using the borehole data of Jones (1996) and interpreted depths from the marine seismic reflection data of Johnson and others (1999), including the detailed surface of the Seattle uplift and basin from Frankel and Stephenson (2000). For the Quaternary thickness through eastern Juan de Fuca Strait, the data of Mosher and Johnson (2000) were incorporated to create the Quaternary-Tertiary interface throughout the northern Puget Lowland.

Quaternary deposits in the Willamette Valley (including the Portland and Tualatin Basins) are generally less than 30 meters $(\mathrm{m})$ in thickness and are not explicitly included in the model region. Future consideration of simulations requiring grid spacing less than $100 \mathrm{~m}$ should explicitly include a thin Quaternary layer. Additionally, recent gravity modeling has suggested that a significant thickness of lowerdensity sediment may exist in the Tualatin basin west of Portland, below the interpreted base of basin sediments in this model (about 6-km depth versus about 1.0-km depth in model V1.6; see McPhee and others, 2014). An image of the Cascadia model V1.6 sliced through the Puget Lowland is shown in figure 5.

The Quaternary $V_{P}$ property model varied onedimensionally with values of $1,500,1,905$, and 1,980 meters per second $(\mathrm{m} / \mathrm{s})$ at 0,200 , and $1,000 \mathrm{~m}$ depth, respectively. These values were derived from land surface measurements and high-resolution marine seismic surveys (Williams and others, 1999; Calvert and others, 2003). The Quaternary $V_{S}$ property model is derived from $V_{S 30}$ and $V_{P 30}$ measurements at the surface to constrain $V_{P} / V_{S}$ ratio to approximately 2.5 . Setting this ratio to 2.5 in the near-surface is also consistent with average borehole measurements in the upper $150 \mathrm{~m}$ by Odum and others (2004). To ensure a contrast in $V_{S}$ at the base of Quaternary deposits, the $V_{P} / V_{S}$ ratio was set to 2.2 at $1 \mathrm{~km}$ depth. The minimum $V_{S}$ in the Quaternary unit, including all non-ocean regions within the model volume, was constrained to $600 \mathrm{~m} / \mathrm{s}$ as a limit for ground motion modeling, although numerous $V_{S}$ measurements demonstrate lower $V_{S}$ in the lowland basins (for example, Williams and others, 1999; Stephenson and others, 2012). The maximum $V_{S}$ within the Quaternary unit was set to $900 \mathrm{~m} / \mathrm{s}$. The overall $V_{S}$-versusdepth structure of the Quaternary deposits is generally consistent with estimates from Odum and others (2004), Delorey and Vidale (2011), and Stephenson and others (2012) in the top kilometer. 


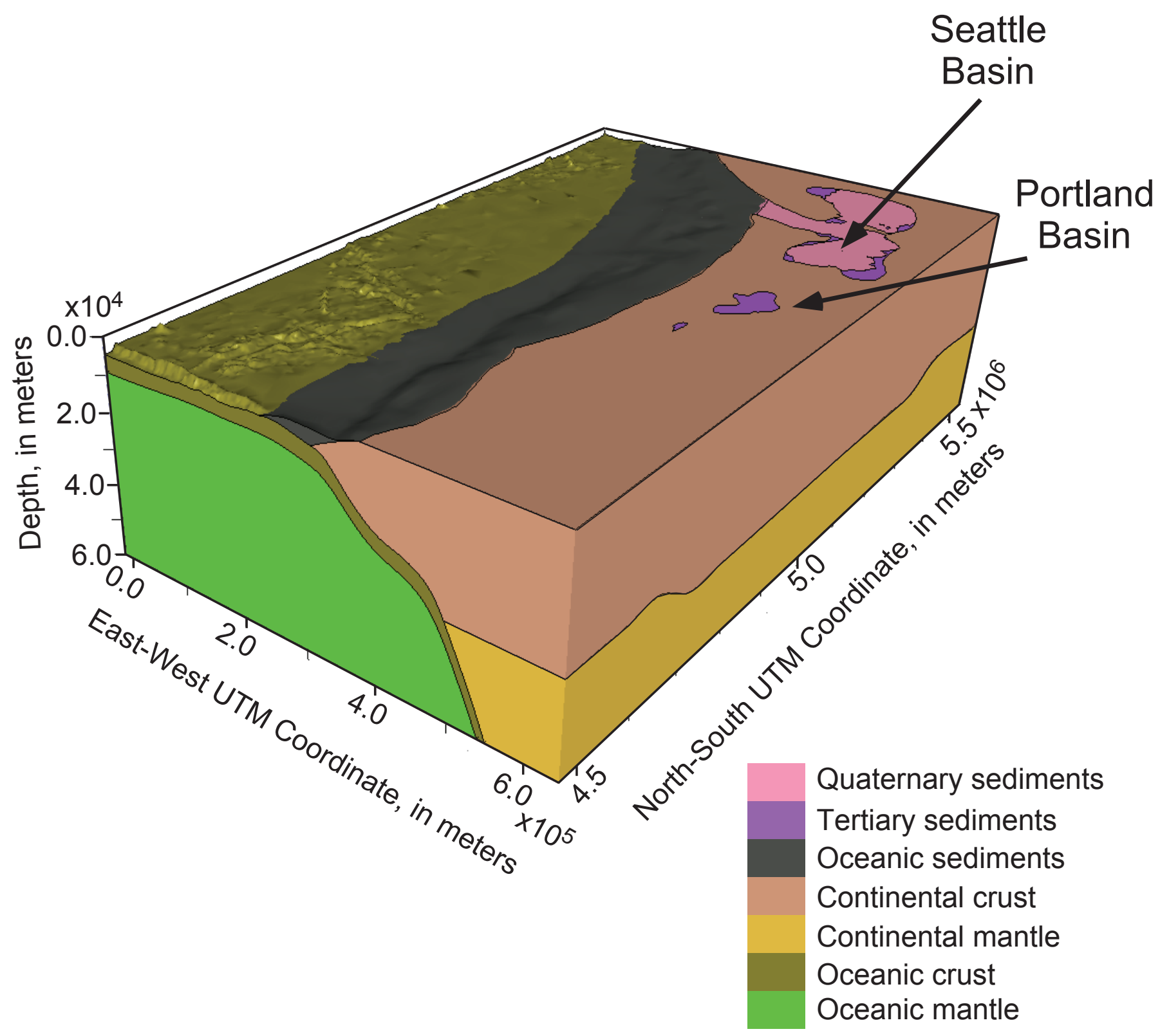

Figure 3. Geologic model volume including the Cascadia subduction zone. $V_{P}$ and $V_{s}$ property models cover the region from $40.2^{\circ}$ to $50^{\circ}$ $\mathrm{N}$. latitude, $122^{\circ}$ to $129^{\circ} \mathrm{W}$. longitude, and from 0- to $60-\mathrm{km}$ depth. Location of Seattle and Portland basins shown by arrows. Axes are annotated in Universal Transverse Mercator (UTM) zone 10 coordinates. Bathymetry $(G E B C O, 2015)$ is included while topography above mean sea level $(0 \mathrm{~m})$ is excluded. Model projected into UTM zone 10 north coordinates, World Geodetic System 1984 (WGS84) datum. View shows the seven basic geology-based model units and their relationships at depth. Cascadia subduction fault surface is inferred along top of oceanic crust model unit. 


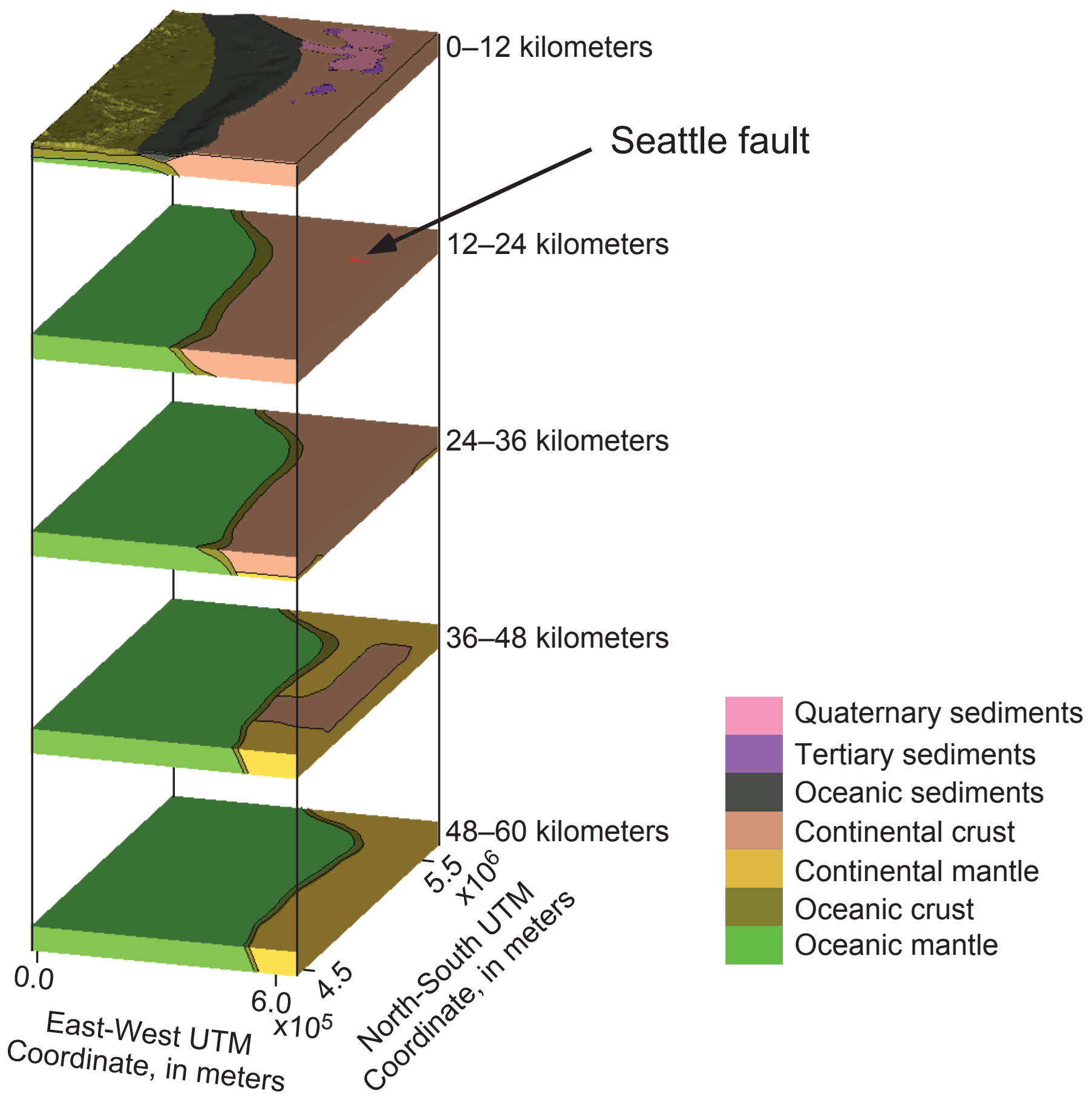

Figure 4. Horizontal subsections through Cascadia model V1.6. Each slab is 12 kilometers (km) thick. Model slabs are orthographically projected for comparison. Location of Seattle fault shown in 12-24 km slab as a red line, underlying the Puget Lowland basins. Slabs cover the entire model volume. 


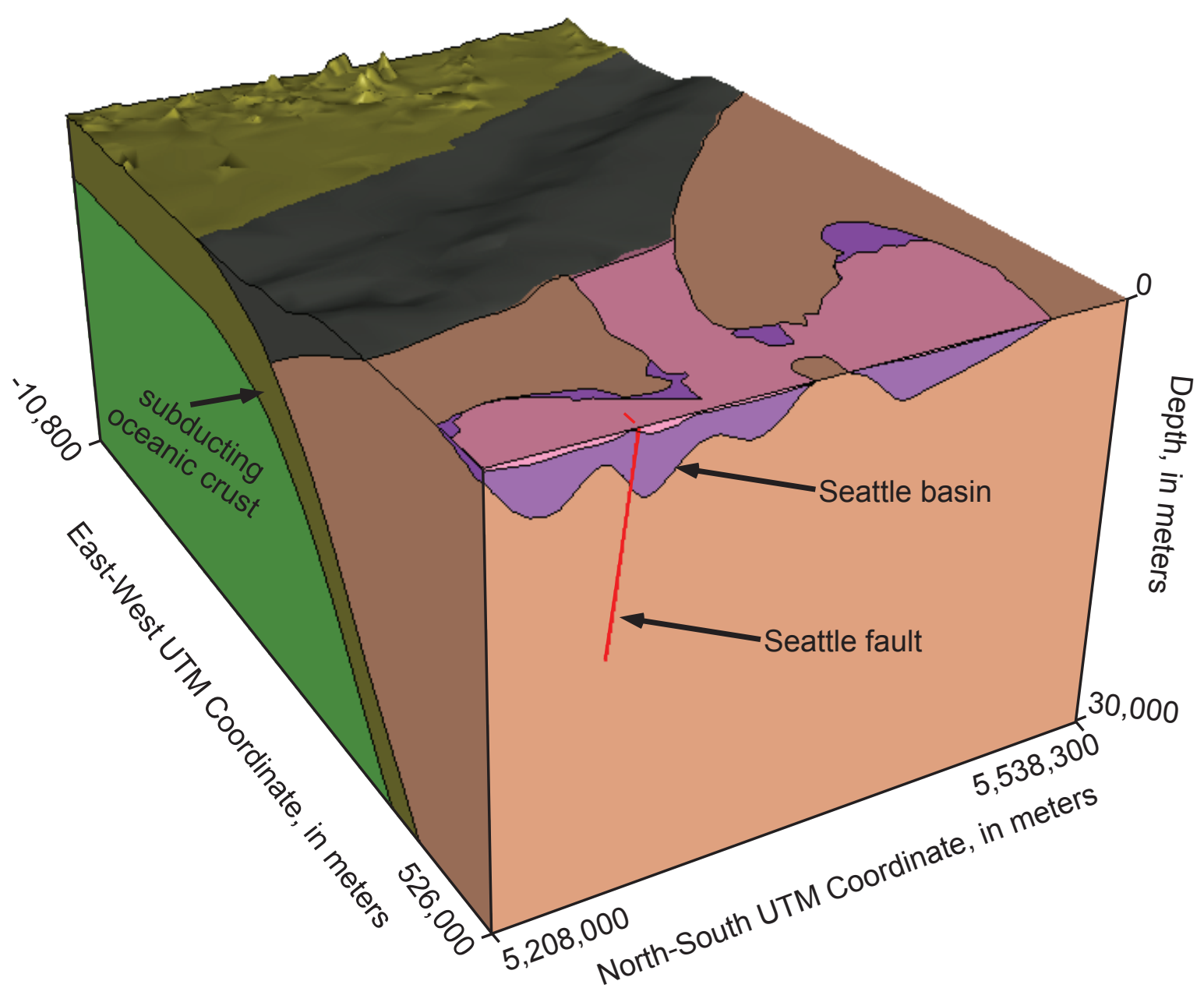

Figure 5. Sliced view of Puget Lowland with Seattle basin. Seattle fault (red line, dashed where projected to surface), and subducting oceanic crust are labeled. Vertical exaggeration is approximately $6 \mathrm{X}$. The Seattle fault dips at $45^{\circ}$ south within the model volume. Axes are annotated in Universal Transverse Mercator (UTM) zone 10 north coordinates. Oceanic mantle unit is green, oceanic crust is olive, oceanic sediments unit is gray, continental crustal unit is tan, Tertiary sediments unit is purple, and Quaternary unit is pink.

The base of the Tertiary sediments within the Puget Lowland is interpreted to be at the $4,500 \mathrm{~m} / \mathrm{s}$ velocity contour, based on oil-industry borehole data (Brocher and Ruebel, 1998). This iso-contour surface was extracted from the Seismic Hazards Investigations in the Puget Sound (SHIPS) and earthquake data 3D P-wave tomography of Ramachandran and others (2006), which incorporate similar data from several previous tomography studies in the lowland (for example, Stanley and others, 1999; Brocher and others, 2001; Van Wagoner and others, 2002). The Portland area sedimentary basin thicknesses are derived from well data that intersect crystalline rocks under (generally) Tertiary deposits (Yeats and others, 1996; Gannett and others, 1998).
$V_{P}$ of the Tertiary subunit in the Puget Lowland basins is defined by tomography of Ramachandran and others (2006). A constant $V_{P} / V_{S}$ ratio of 2 was imposed on the Tertiary subunit to obtain $V_{S}$. This value was selected to ensure a distinct contrast in $V_{S}$ at the contact between the continental crust and Tertiary geologic units that are broadly consistent with $V_{S}$ interpreted by Snelson and others (2007). $V_{P}$ parameters within the Willamette Valley basin deposits were similar to the velocity-versus-depth structure of the Puget Lowland with several exceptions. Because Quaternaryage deposits are not explicitly defined in the basins within the Willamette Valley, the upper $100 \mathrm{~m}$ was sufficiently lowered to represent "Quaternary-like" deposits. In a manner similar 
to our treatment of shallow $V_{P}, V_{S}$ at the surface was set to approximate $V_{S 30}$ values in the Willamette Valley region using data from Odum and others (2010) to represent lower-velocity Quaternary deposits. A $V_{P} / V_{S}$ ratio of 2 was imposed on the Tertiary subunit in this region to calculate $V_{P}$ at the surface, to be consistent with the surface $V_{S}$ values of Odum and others (2010), while $V_{S}$ to the base of the valley sediments was calculated from $V_{P}$.

\section{Continental Crust}

The surface of the continental crust was set to mean sea level (MSL) outside of sedimentary basins and east of the oceanic sedimentary deposits (see fig. 3) because topography is not included in model V1.6. The surface of the continental crust below MSL was controlled by a smoothed continental shoreline and numerous published active and passive source seismic results along the continental margin (for example, Trehu and others, 1994; Clowes and others, 1997; Flueh and others, 1998; Fuis, 1998; Gulick and others 1998; Fleming and Trehu, 1999; Parsons and others, 1999; Stanley and Villaseñor, 2000; Bostock and others, 2002; and Ramachandran and others, 2006).

Two primary datasets were integrated to form the $V_{P}$ and $V_{S}$ property volumes within the continental crust. The SHIPS tomographic data (Ramachandran and others, 2006) formed the basis for $V_{P}$ throughout the Puget Lowland region, while the tomographic data of Moschetti and others (2007) formed the basis of $V_{S}$ throughout the remainder of the model volume. We once again rely on the empirical relationships between $V_{P}$ and $V_{S}$ of Brocher (2005) to calculate the companion property for both of these tomographic datasets. The final $V_{P}$ and $V_{S}$ property data were merged prior to volumetric gridding within the geologic unit. Although not directly incorporated into the property calculation, the $V_{P}$ values calculated for the unit are broadly consistent with the numerous studies referenced above.

\section{Continental Mantle}

The top of the continental mantle is derived from data of Bassin and others (2000). These data were edited and smoothed to create the surface of this unit. Property $V_{S}$ was derived from the tomography results of Moschetti and others (2007). The $V_{S}$ tomography of Moschetti and others (2007) was used to define $V_{P}$ throughout the geologic unit from the relationships of Brocher (2005). These $V_{P}$ are generally consistent with the earlier tomography of Stanley and others (1999) from the Puget Lowland area, which was used to constrain upper mantle $V_{P}$ in model V1.3.

\section{Oceanic Sediment}

The oceanic sediment unit represents the accretionary wedge, composed of accreted oceanic and continentally derived sedimentary deposits, which overlies the top of the continental crustal unit and the subducting oceanic crust. The eastern portion of the bathymetric surface was used to define elevation at the top of the oceanic sediment (figs. 3 and 5). Parameter $V_{P}$ is derived from results of Parsons and others (1999) and numerous active-source marine seismic surveys (Trehu and others, 1994; Clowes and others, 1997; Flueh and others, 1998; Fuis, 1998; Gulick and others, 1998; Fleming and Trehu, 1999; Parsons and others, 1999; Stanley and Villaseñor, 2000; Bostock and others, 2002). Parameter $V_{P}$ varies primarily as a function of depth. $V_{S}$ was derived from $V_{P}$ using the empirical relationship of Brocher (2005). The ground motion simulation study of Olsen and others (2008) suggests this unit will be subject to intense shaking during a Cascadia megathrust event, due in part to its proximity to the fault. Although this study used model V1.3, there are very minor differences in this unit's properties and geometry within model V1.6.

\section{Oceanic Crust}

The top of the subducting oceanic crust unit is defined by Blair and others (2011) and McCrory and others (2012). These data were merged with bathymetric data (GEBCO, 2015) west of the oceanic sediment terminus to create the upper surface of the oceanic crust, which in the subsurface is inferred to be the top of the Cascadia subducting slab. Based on available marine seismic-reflection profiling (for example, Fuis, 1998) and studies worldwide (for example, Turcotte and Shubert, 1982), the thickness of the oceanic crust was set to $5,000 \mathrm{~m}$, which is likely on the low end of realistic values. Average velocity values derived from marine seismic surveys were extrapolated to obtain $V_{P}$ (for example, Trehu and others, 1994; Flueh and others, 1998; Fuis, 1998; Gulick and others, 1998; Fleming and Trehu, 1999; and Ramachandran and others, 2006) and extrapolated uniformly to $60,000 \mathrm{~m}$ depth. $V_{S}$ was derived from $V_{P}$ using the empirical relationship of Brocher (2005).

\section{Oceanic Mantle}

The oceanic mantle is the only unit in the model underlying oceanic crust (fig. 4). The upper surface of the oceanic mantle unit is derived by down-projecting the top of the oceanic crust $5,000 \mathrm{~m}$ and smoothing the resulting surface to mitigate topographic anomalies from the bathymetry data. This unit is the least constrained in both $V_{P}$ and $V_{S}$ parameters because of limited published results. Based on the imaging results of Parsons and others (1999) and Flueh and others (1998), parameter $V_{P}$ was set to vary from 7,900 to $8,300 \mathrm{~m} / \mathrm{s}$ between about 10,000 and 60,000 $\mathrm{m}$ depth, respectively. $V_{S}$ was derived from $V_{P}$ using the empirical relationship of Brocher (2005). 


\section{Discussion}

$V_{S}$ and $V_{P}$ throughout the model are shown in figures 6-9. $V_{S}$ velocities range from 600 to $4,830 \mathrm{~m} / \mathrm{s}$. Figure 6 shows east-west oriented vertical slices through the $V_{S}$ model, spaced every $200 \mathrm{~km}$. These slices reveal the subducting slab and regions of the model with higher apparent resolution in the shallow continental crust such as western Washington State. In large part, this is due to the high resolution $V_{P}$ tomography results from the SHIPS data (for example, Brocher and others, 2001; Ramachandran and others, 2006). Similarly, depth slices through the $V_{S}$ property volume from 9,000 to $45,000 \mathrm{~m}$ spaced every $9,000 \mathrm{~m}$, are shown in figure 7 . The $9,000 \mathrm{~m}$ depth slice reveals the subducting oceanic crust as the arc-shaped orange-colored band of approximately $3,300 \mathrm{~m} / \mathrm{s}$. The region covered by the SHIPS tomography highlights the greater variability in the northeast quadrant of this slice beneath the sedimentary basins of the Puget Lowland. This subducting unit is visible in the depth slices to at least $-45,000 \mathrm{~m}$ depth. Throughout the model volume, oceanic mantle $V_{S}$ is consistently higher than continental units at a given depth slice. As shown in figures 8 and 9, the $V_{P}$ property values range from about 1,100 to $8,450 \mathrm{~m} / \mathrm{s}$ in the 3D property model. Many of the velocity trends and features observed in the $V_{S}$ property slices are similar to those in the $V_{P}$ property volume.

As of FY2017, model version V1.6 has undergone preliminary validation exercises (for example, Vidale and others, 2016) as part of the National Science Foundation funded M9 Project, a collaborative effort through the University of Washington whose goal is "to reduce catastrophic potential effects of a Cascadia megathrust earthquake on social, built and natural environments..." (https://hazards.uw.edu/geology/m9/). The model volume of model V1.3 in the immediate vicinity of Seattle, which is largely unchanged in model V1.6, was partially validated through qualitative waveform matching with ground motion simulations of the $2001 \mathrm{M} 6.8$ Nisqually earthquake (to $1 \mathrm{~Hz}$ ) as well as other weak-motion events (Frankel and others, 2007). The $V_{S}$ and $V_{P}$ model volumes were implemented in these ground motion simulations, and these results were incorporated into the U.S. Geological Survey (USGS) Urban Hazards Maps for Seattle. The Seattle urban hazard model volume was a subset of the greater Cascadia velocity model volume that is the focus of the M9 project.

The depth to shear-wave velocity of $2,500 \mathrm{~m} / \mathrm{s}(\mathrm{Z} 2.5)$ is a parameter currently used for estimating long-period site response in international building codes (International Code Council [ICC], 2015). The Z2.5 parameter for the Puget Sound region from model V1.6 will be contributed to the database of Ahdi and others (2017), for building design parameters in the Pacific Northwest, as well as to the NCM (Boyd and Shah, 2016).

The ratio of P-wave velocity to S-wave velocity $\left(V_{P} / V_{S}\right)$ throughout the geologic units is consistent with expected values as described in publications on the topic (for example, Turcotte and Schubert, 1982). The $V_{P} / V_{S}$ depth slices, shown in figure 10, reveal that nominal ratios in the deeper crust and mantle range between 1.71 and 1.76. The mean $V_{P} / V_{S}$ ratio between 8,000 and $60,000 \mathrm{~m}$ depth is approximately 1.734, similar to a Poisson solid value of 1.732 for elastic material. Property $V_{P} / V_{S}$ varies most markedly at depths from about $9,000 \mathrm{~m}$ to the surface, where the ratio is as high as 2.5 in the upper few hundred meters, as described previously in the section on the Continental Sedimentary Basins unit. 


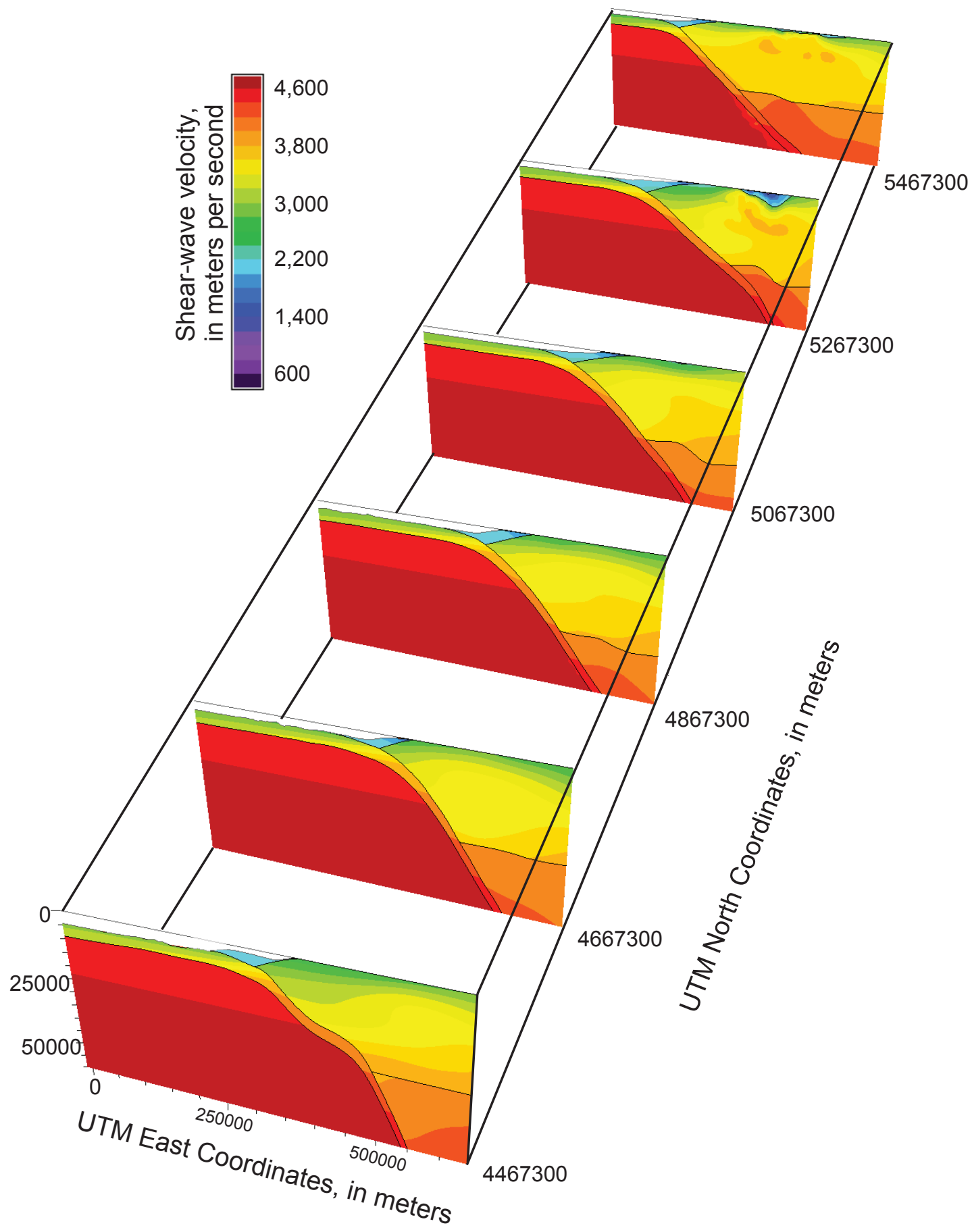

Figure 6. East-west slices through $V_{s}$ model, spaced every 200 kilometers $(\mathrm{km})$. Velocities are scaled from 400 to 4,800 meters per second (m/s). Water velocity of Pacific Ocean is set to $0 \mathrm{~m} / \mathrm{s}$. 


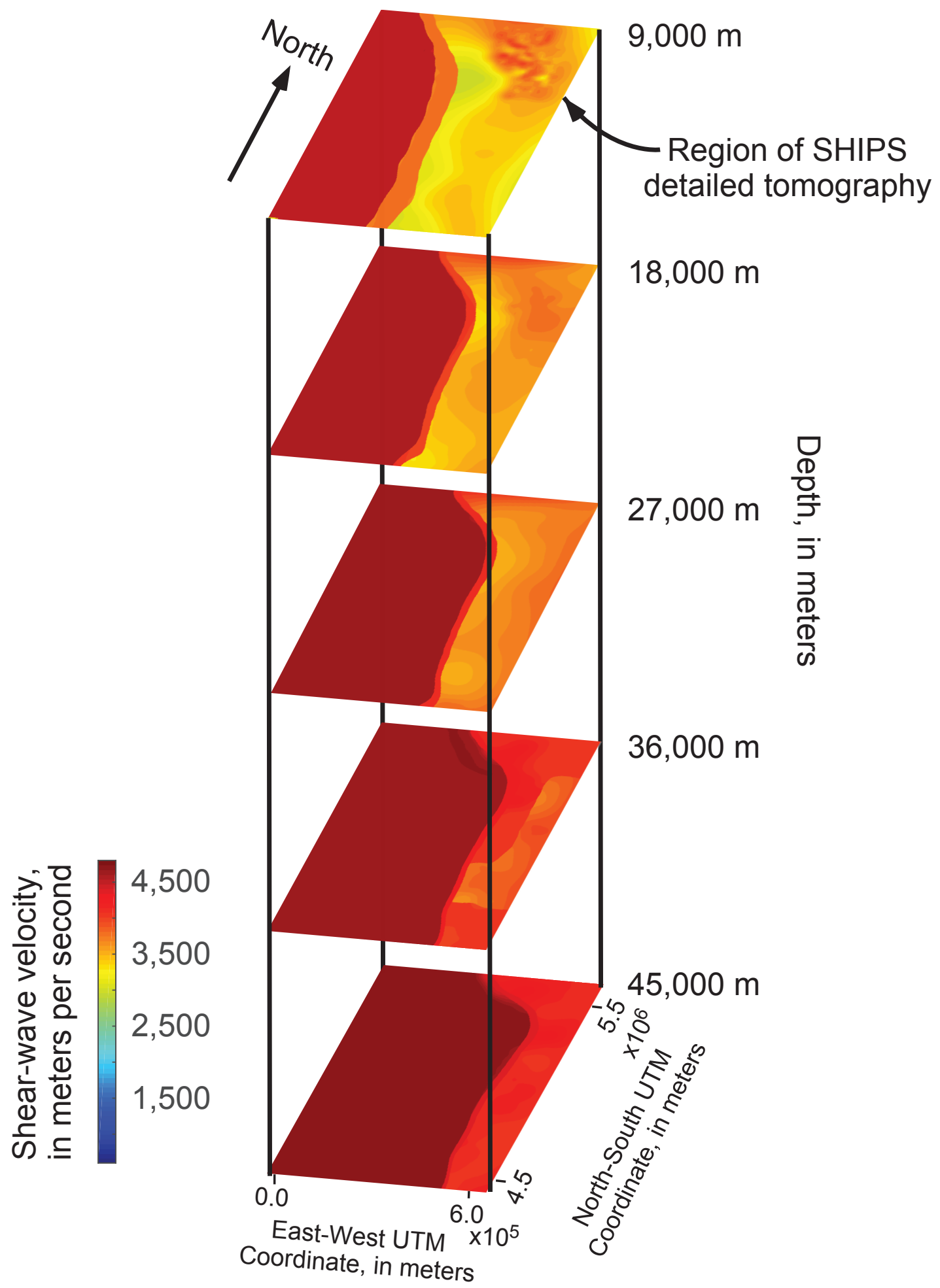

Figure 7. $V_{s}$ horizontal model slices at 9,000 meter $(\mathrm{m})$ to $45,000 \mathrm{~m}$ depth intervals, spaced every $9,000 \mathrm{~m}$. Area of each slice covers entire extent of model. 


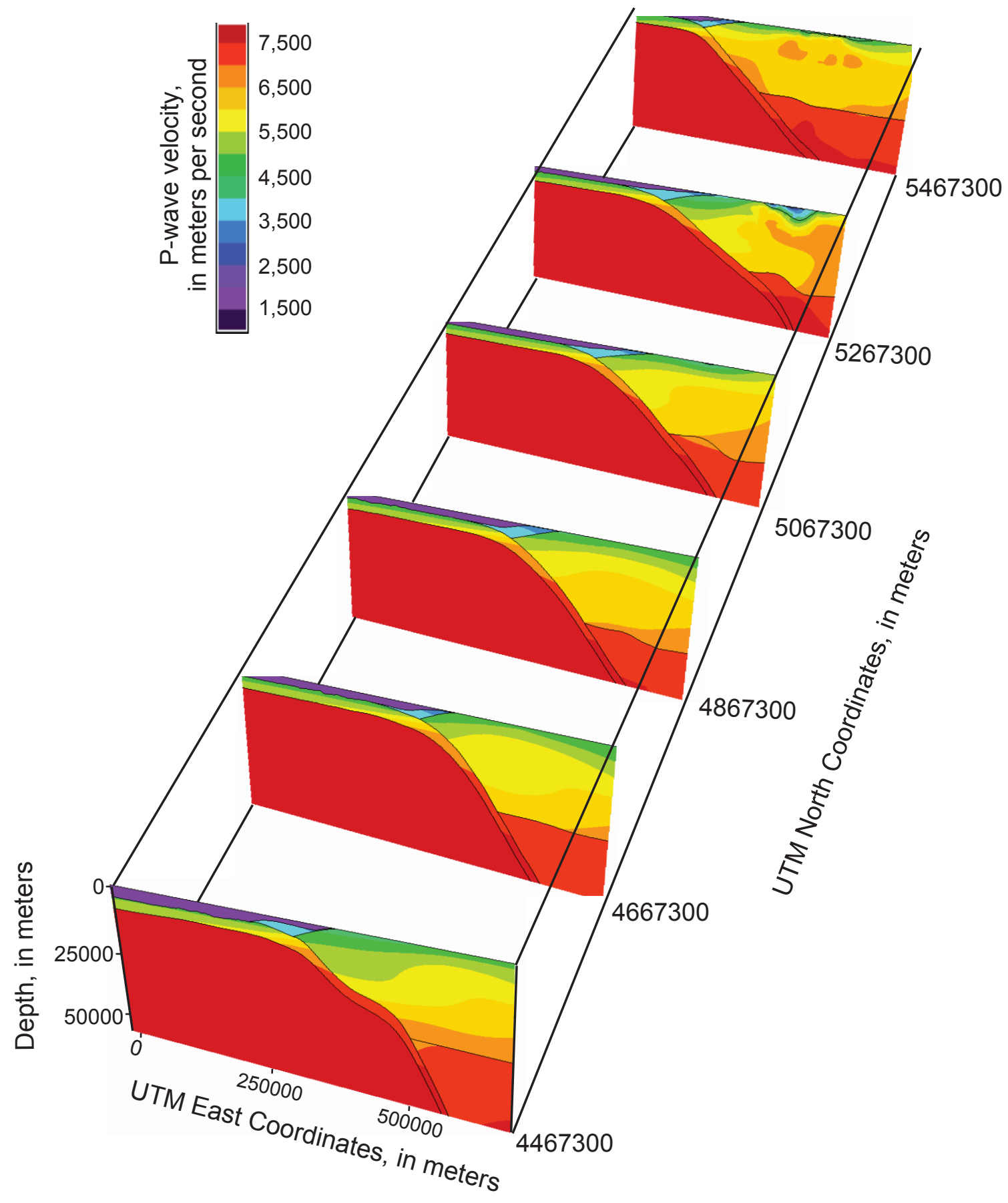

Figure 8. East-west slices through $V_{p}$ model, spaced every 200 kilometers $(\mathrm{km})$. Velocities are scaled from 1,500 to 7,500 meters per second $(\mathrm{m} / \mathrm{s})$. Water velocity of Pacific 0 cean is set to $1,500 \mathrm{~m} / \mathrm{s} . V_{p}$ property slices correspond in Universal Transverse Mercator (UTM) zone 10 north to the $V_{s}$ slices in figure 6. 


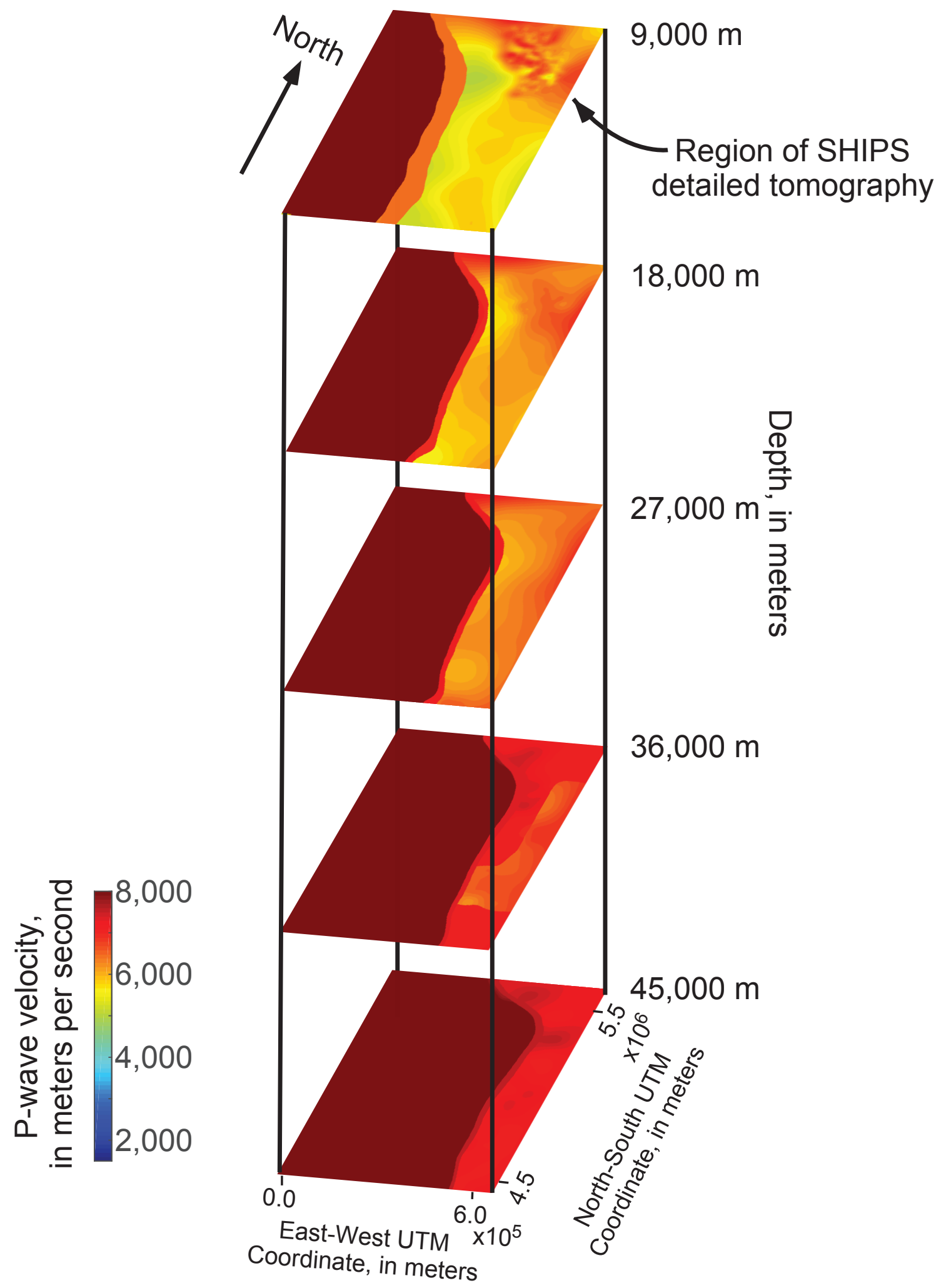

Figure 9. $\quad V_{p}$ horizontal model slices at 9,000 meter $(\mathrm{m})$ to $45,000 \mathrm{~m}$ depth intervals, spaced every $9,000 \mathrm{~m}$. Area of each slice covers entire extent of model. (Same depths as slices shown in fig. 7). 


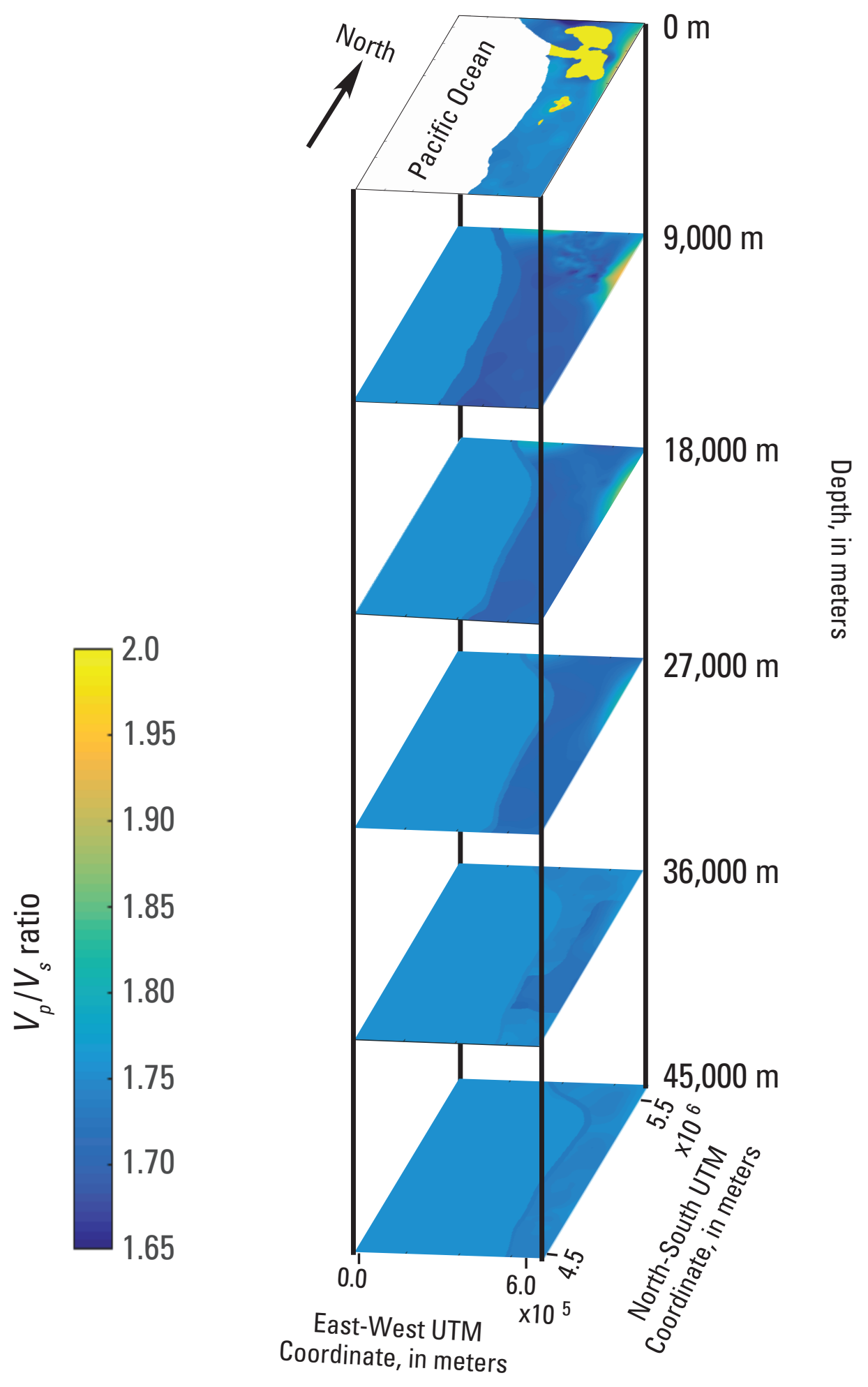

Figure 10. $\quad V_{p} / V_{s}$ horizontal model slices from 0 meter $(\mathrm{m})$ to $45,000 \mathrm{~m}$ depth, spaced every $9,000 \mathrm{~m}$. Area of each slice covers entire extent of model. 


\section{Summary}

The $3 \mathrm{D}$ velocity property models described in this paper were developed between fiscal years 2010 and 2016 for use in strong ground motion simulations of the Seattle fault, Cascadia subduction, and similar earthquake events of interest. These models were derived primarily from published geophysical data in addition to borehole and other geological constraints. The model volume V1.6 as developed in EarthVision is designed to be flexible and can be modified to add further complexity as new published information becomes available or as scientific focus is redirected to new challenges in the Cascadia region. This flexibility allows model grid, or node, spacing to be customized from the EarthVision model for a user's specific purpose. The model can be obtained at $500 \mathrm{~m}$ resolution in zip-compressed ASCII format from ScienceBase (https://doi.org/10.5066/F7NS0SWM).

\section{References Cited}

Ahdi, S.K., Stewart, J.P., Ancheta, T.D., Kwak, D.Y., and Mitra, Devjyoti, 2017, Development of $V_{S}$ Profile database and proxy-based models for $V_{S 30}$ prediction in the Pacific Northwest region of North America: Bulletin of the Seismological Society of America, v. 107, no. 4, p. 1718-1801, doi:10.1785/0120160335.

Bassin, C., Laske, G., and Masters, G., 2000, The current limits of resolution for surface wave tomography in North America, EOS Trans AGU, 81, F897.

Blair, J.L., McCrory, P.A., Oppenheimer, D.H., and Waldhauser, F., 2011, revised 2013, A geo-referenced 3D model of the Juan de Fuca Slab and associated seismicity: U.S. Geological Survey Data Series 633, v. 1.2, https://pubs.usgs.gov/ds/633/.

Blakely, R.J., Wells, R.E., Weaver, C.S., and Johnson, S.Y., 2002, Location, structure, and seismicity of the Seattle fault zone, Washington-Evidence from aeromagnetic anomalies, geologic mapping, and seismic-reflection data: Geological Society of America Bulletin, v. 114, p. 169-177.

Bostock, M.G., Hyndman, R.D., Rondenay, S., and Peacock, S.M., 2002, An inverted continental Moho and serpentinization of the forearc mantle: Nature, v. 417, p. 536-538.

Boyd, O.S., and Shah, A.K., 2016, Progress on the USGS National Crustal Model for seismic hazard studies: Seismological Research Letters, v. 87, no. 2B, p. 583.

Brocher, T.M., 2005, Empirical relations between elastic wavespeeds and density in the Earth's crust: Bulletin of the Seismological Society of America, v. 95, no. 6, p. 20812092.
Brocher, T.M., Parsons, T., Blakely, R.J., Christensen, N.I., Fisher, M.A., Wells, R.E., and SHIPS Working Group, 2001, Upper crustal structure in Puget Lowland, Washington-Results from the 1998 Seismic Hazards Investigation in Puget Sound: Journal of Geophysical Research, v. 106, no. B7, p. 13541-13564.

Brocher, T.M., and Ruebel, A.L., 1998, Compilation of 29 sonic and density logs from 23 oil test wells in western Washington State: U.S. Geological Survey Open-File Report 98-249, 60 p.

Calvert, A.J., Fisher, M.A., Johnson, S.Y., Brocher, T.M., Creager, K.C., Crosson, R.S., Hyndman, R.D., Miller, K.C., Mosher, D., Parsons, T., Pratt, T.L., Spence, G., ten Brink, U., Trehu, A.M., and Weaver, C.S., 2003, Along-strike variations in the shallow seismic velocity structure of the Seattle fault zone-Evidence for fault segmentation beneath Puget Sound: Journal of Geophysical Research, v. 108, p. ESE1-14.

Clowes, R.M., Baird, D.J., and Dehler, S.A., 1997, Crustal structure of the Cascadia subduction zone, southwestern British Columbia, from potential field and seismic studies: Canadian Journal of Earth Science, v. 34, p. 317-335.

Delorey, A.A., and Vidale, J.E., 2011, Basin shear-wave velocities beneath Seattle, Washington, from noise-correlation Rayleigh waves: Bulletin of the Seismological Society of America, v. 101, no. 5, p. 2162-2175.

Fleming, S.W., and Trehu, A.M., 1999, Crustal structure beneath the central Oregon convergent margin from potential-field modeling - Evidence for a buried basement ridge in local contact with a seaward dipping backstop: Journal of Geophysical Research, v. 104, no. B9, p. 20431-20447.

Flueh, E.R., Fisher, M.A., Bials, Joerg, Childs, J.R., Klaeschen, Dirk, Kukowski, Nina, Parsons, Thomas, Scholl, D.W., ten Brink, Uri, Trehu, A.M., and Vidal, Neus, 1998, New seismic images of the Cascadia subduction zone from cruise SO108 - ORWELL: Tectonophysics, v. 293, p. 69-84.

Frankel, A.D., and Stephenson, W.J., 2000, Modeling observed ground motions in Seattle using three-dimensional simulations: Bulletin of the Seismological Society of America, v. 90 , no. 5 , p. 1251-1267.

Frankel, A.D., Stephenson, W.J., Carver, D.L., Williams, R.A., Odum, J.K., and Rhea, Susan, 2007, Seismic hazard maps for Seattle, Washington incorporating 3D sedimentary basin effects, nonlinear site response, and rupture directivity: U.S. Geological Survey Open-File Report 2007-1175, 77 p.

Fuis, G.S., 1998, West margin of North America-A synthesis of recent seismic transects: Tectonophysics, v. 288, p. 265-292. 
Gannett, M.W., and Caldwell, R.R., 1998, Geologic framework of the Willamette Lowland aquifer system, Oregon and Washington: U.S. Geological Survey Professional Paper 1424-A, 32 p., 8 pls.

General Bathymetric Chart of the Oceans (GEBCO), 2015, The GEBCO_2014 Grid, version 20150318, http://www.gebco.net.

Gulick, S.P.S., Meltzer, A.M., and Clarke, S.H., 1998, Seismic structure of the southern Cascadia subduction zone and accretionary prism north of the Mendocino triple junction: Journal of Geophysical Research, v. 103, no. B11, p. $27207-27222$.

International Code Council, 2015, 2015 International Building Code: Washington, D.C., International Code Council Governmental Affairs Office.

Johnson, S.Y., Dadisman, S.V., Childs, J.R., and Stanley, W.D., 1999, Active tectonics of the Seattle fault and central Puget Sound, Washington-Implications for earthquake hazards: Geological Society of America Bulletin, v. 111, p. 1042-1053.

Jones, D.L., Silberling, N.J., and Hillhouse, John, 1977, Wrangellia-A displaced terrane in northwestern North America: Canadian Journal of Earth Science, v. 14, p. 2565-2577.

Jones, M.A., 1996, Thickness of unconsolidated deposits in the Puget Sound Lowland, Washington and British Columbia: U.S. Geological Survey Water-Resources Investigations Report WRI 94-4133, 1 pl., scale 1:450,000.

McCrory, P. A., Blair, J.L., Waldhauser, Felix, and Oppenheimer, D.H., 2012, Juan de Fuca slab geometry and its relation to Wadati-Benioff zone seismicity: Journal of Geophysical. Research, v. 117, B09306, doi:10.1029/2012JB009407.

McPhee, D.K., Langenheim, V.E., Wells, R.E., and Blakely, R.J., 2014, Tectonic evolution of the Tualatin basin, northwest Oregon, as revealed be inversion of gravity data: Geosphere, v. 10, p. 264-275, doi:10.1130/GES00929.1.

Molnar, Sheri, Cassidy, J.J., Olsen, K.B., Dosso, S.E., and He, Jianghengs, 2014, Earthquake ground motion and 3D Georgia Basin amplification in southwest British Columbia - deep Juan de Fuca plate scenario earthquakes: Bulletin of the Seismological Society of America, v. 104, no. 1, p. 301-320.

Moschetti, M.P., Ritzwoller, M.H., and Shapiro, N.M., 2007, Surface wave tomography of the western United States from ambient noise- Rayleigh wave group velocity maps: Geochemisty, Geophysics, and Geosystems, v. 8, Q08010, doi: 10.1029/2007GC001655.
Mosher, D.C., and Johnson, S.Y., 2000, Juan de Fuca atlasNeotectonics of the eastern Juan de Fuca Strait. A digital geological and geophysical atlas: Geological Survey of Canada Open-File no. 3931.

Odum, J.K., Stephenson, W.J., Goetz-Troost, Kathy, Worley, D.M., Frankel, A.D., Williams, R.A., and Frier, Jake, 2004, Shear- and compressional- wave velocity measurements from two 150-m-deep boreholes in Seattle, Washington, USA: U.S. Geological Survey Open-File Report 04-1419, 36 p. [Available at http://pubs.usgs.gov/of/2004/1419/.]

Odum, J.K., Stephenson, W.J., Maharrey, J.Z., Frary, R.N., and Dart, R.L., 2010, Preliminary results from a multi-method approach for acquiring shear-wave velocity data in the Portland and Tualatin basins, Oregon [abs.], in Seismological Society of America (SSA) 2010 Abstracts of the Annual Meeting, Portland, Oreg., March/April 2010: Seismological. Research Letters, v. 81, no. 2, p. 358.

Olsen, K.B., Stephenson, W.J., and Geisselmeyer, Andreas, 2008, 3D crustal structure and long-period ground motions from a M9.0 megathrust earthquake in the Pacific Northwest region: Journal of Seismology, v. 12, no. 2, p. 145159, doi:10.1007/s10950-007-9082-y.

Parsons, T., Wells, R.E., Fisher, M.A., Flueh, E., and ten Brink, U.S., 1999, Three-dimensional velocity structure of Siletzia and other accreted terranes in the Cascadia forearc of Washington: Journal of Geophysical Research, v. 104, no. B8, p. 18015-18039.

Pratt, T.L., Johnson, S.Y., Potter, C.J., Stephenson, W.J., and Finn, Carol, 1997, Seismic reflection images beneath Puget Sound, western Washington State-The Puget Lowland thrust sheet hypothesis: Journal of Geophysical Research, v. 102, no. B12, p. 27469-27489.

Ramachandran, Kumar, Hyndman, R.D., and Brocher, T.M., 2006, Regional P wave velocity structure of the northern Cascadia subduction zone: Journal of Geophysical Research, v. 111, no. B12, p. B12, 301.

Schuster, E.J., 2005, Geologic map of Washington State: Washing State Department of Natural Resources, scale 1:500,000.

Shaw, J.H., Plesch, Andreas, Tape, Carl, Suess, M.P., Jordan, T.H., Ely, Geoffrey, Hauksson, Egill, Tromp, Jeroen, Tanimoto, Toshiro, Graves, Robert, Olsen, Kim, Nicholson, Craig, Maechling, P.J., Rivero, Carlos, Lovely, Peter, Brankman, C.M., and Munster, Jason, 2015, Unified structural representation of the southern California crust and upper mantle: Earth and Planetary Science Letters, v. 415, p. 1-15. 
Snelson, C.M., Brocher, T.M., Miller, K.C., Pratt, T.L., and Trehu, A.M., 2007, Seismic amplification within the Seattle Basin, Washington State-Insights from SHIPS seismic tomography experiments: Bulletin of the Seismological Society of America, v. 97, no. 5, p. 1432-1448.

Stanley, Dal, and Villaseñor, Antonio, 2000, Models of downdip frictional coupling for the Cascadia megathrust: Geophysical Research Letters, v. 27, no. 10, p. 1551-1554.

Stanley, Dal, Villaseñor, Antonio, and Benz, Harley, 1999, Subduction zone and crustal dynamics of western Washington-A tectonic model for earthquake hazards evaluation: U.S. Geological Survey Open-File Report 99-311, 90 p.

Stephenson, W.J., 2007, Velocity and density models incorporating the Cascadia subduction zone for 3D earthquake ground motion simulations, version 1.3: U.S. Geological Survey Open-File Report 2007-1348, 24 p. [Available at https://pubs.usgs.gov/of/2007/1348/.]

Stephenson, W.J., and Frankel, A.D., 2003, Development of a $3 \mathrm{D}$ velocity and density model for the Cascadia subduction zone and preliminary finite-difference modeling results: Geological Society of America Abstracts with Programs, v. 35 , no. 6 , p. 263.

Stephenson, W.J., Odum, J.K., Dart, R.L., Angster, S.J., and Worley, D.M., 2012, Characterization of shallow S-wave velocities across the Tacoma Basin, Washington State, from SPAC AND HVSR Microtremor Analyses: Seismological Research Letters, v. 83, no. 2, p. 378.

ten Brink, U.S., Molzer, P.C., Fisher, M.A., Blakely, R.J., Bucknam, R.C., Parsons, Tom, Crosson, R.S., and Creager, K.C., 2002, Subsurface geometry and evolution of the Seattle fault zone and the Seattle Basin, Washington: Bulletin of the Seismological Society of America, v. 92, no. 5 , p. 1737-1753.
Trehu, A.M., Asudeh, Isa Brocher, T.M., Luetgert, J.H., Mooney, W.D., Nabelek, J.L., and Nakamura, Yosio, 1994, Crustal architecture of the Cascadia forearc: Science, v. 266, p. 237-242.

Turcotte, D.L., and Schubert, Gerald, 1982, GeodynamicsApplications of continuum physics to geological problems: New York, John Wiley \& Sons, p. 12.

Van Wagoner, T.M., Crosson, R.S., Creager, K.C., Medema, G.F., Preston, L.A., Symons, N.P., and Brocher, T.M., 2002, Crustal structure and relocated earthquakes in the Puget Lowland, Washington, from high-resolution seismic tomography: Journal of Geophysical Research, v. 107, p. $2381-2403$.

Vidale, J.E., Wirth, E.A., Frankel, A.D., Baker, Ben, Thompson, Mika, Han, Jiangang, Nasser, Marafi, and Stephenson, W.J., 2016, Refined modeling of Seattle Basin amplification [abs.], in 2016 Fall Meeting of the American Geophysical Union, San Francisco, 12-16 Dec., 2016 : American Geophysical Union, Abstracts \#S31C-2781.

Wagner, T.A., Schlamminger, Stephan, Gundlach, J.H., and Adelberger, E.G., 2012, Torsion-balance tests of the weak equivalence principle: Classical and Quantum Gravity, v. 29 , no. 18 , p. 184002 .

Williams, R.A., Stephenson, W.J., Frankel, A.D., and Odum, J.K., 1999, Surface seismic measurements of near-surface $\mathrm{P}$ - and S-wave seismic velocities at earthquake recording stations, Seattle, Washington: Earthquake Spectra, v. 15, no. 3 , p. 565-584.

Yeats, R.S., Graven, E.P., Werner, K.S., Goldfinger, Chris, and Popowski, T.A., 1996, Tectonics of the Willamette Valley, Oregon, in Rogers, A.M., Walsh, T.J., Kockelman, W.J., and Priest, G.R., eds., Assessing earthquake hazards and reducing risk in the Pacific Northwest, volume 1: U.S. Geological Survey Professional Paper 1560, p. 183-222. 

For more information concerning this publication, contact: Center Director, USGS Geologic Hazards Science Center Box 25046, Mail Stop 966

Denver, CO 80225

(303) 273-8579

Publishing support by:

The Denver and Pembroke Publishing Service Centers 
